\title{
Kerusuhan Massa oleh Supporter Persebaya
}

\author{
Didik Wahyudi \\ \begin{tabular}{l|l} 
d_wahyu.di@gmail.com & $\begin{array}{l}\text { ST'AI Al-Azhar Menganti Krajan } \\
\text { Gg.7 No.474 Gresi }\end{array}$
\end{tabular}
}

\begin{abstract}
Football supporters are the twelfth players who are arguably the most fanatical and enthusiastic in defending the club they love. Unfortunately, when they support their team, sometimes they commit mass riots by committing criminal acts as the destruction of property, illtreatment, and humiliation. This paper aims to find out (1) how the mass riots transpired by PERSEBAYA Supporters and (2) how the juridical perspective and Islamic criminal law against the mass riots. At the end of the paper, two things were concluded. Firstly, that the mass riots committed by PERSEBAYA's Supporters in Surabaya were triggered by excessive fanaticism. Secondly, according to Islamic criminal law, it is included in the category of criminal acts of injury, torture, and vandalism, whether intentionally or intentionally. The reason for legal responsibility is because the Persebaya Supporter riots producing harm unto others and this must be legally processed either Islamic law or Positive law.
\end{abstract}

Keywords: Mass Riot, Persebaya Supporters, Islamic Criminal Law

\begin{abstract}
Abtrsak: Suporter sepak bola merupakan pemain keduabelas yang dibilang paling fanatik dan antusias dalam membela klub yang dicintainya. Sayangnya ketika mereka mendukung tim kesayanggannya secara berlebihan, terkadang mereka melakukan kerusuhan massa, berupa tindak pidana perusakan barang, penganiayaan, dan penghinaan. Tulisan ini bertujuan untuk mengetahui (1) bagaimana terjadinya kerusuhan massa yang dilakukan oleh Supporter PERSEBAYA dan (2) bagaimana tinjauan yuridis dan prespektif hukum pidana Islam terhadap kerusuhan massa tersebut. Di akhir tulisan disimpulkan dua hal. Pertama, bahwa terjadinya kerusuhan massa yang yang dilakukan Supporter PERSEBAYAdi Surabaya dipicu oleh kefanatikan yang berlebih dari Supporter Persebaya tersebut kepada kesebelasan sepakbola (persebaya). Kedua bahwa menurut hukum pidana Islam sudah termasuk dalam kategori tindak pidana pelukaan, penganiayaan, dan pengerusakan baik itu tidak sengaja atau karena sengaja.
\end{abstract}


Karena di sini kerusuhan Supporter Persebaya melakukan tindakan yang bisa merugikan orang lain dan hal ini harus diproses secara hukum baik itu hukum Islam ataupun hukum menurut KUHP.

Kata kunci: Kerusuhan masa, suporter persebaya, dan kerususuhan dalam fiqh jinayah

\section{Pendahuluan}

Perbuatan manusia dinilai sebagai pelanggaran atau kejahatan kepada sesamanya, apabila pelanggaran atau kejahatan tersebut mengenai fisik atau non fisik, seperti membunuh, melukai, menuduh maupun kejahatan terhadap harta benda dan lainnya. ${ }^{1}$

Perbuatan tersebut termasuk perbuatan pidana, yakni perbuatan yang dilarang oleh aturan hukum dan barang siapa yang melanggar larangan tersebut dikenakan sanksi pidana. ${ }^{2}$ Dalam rumusan tersebut, dasar yang dilarang adalah perbuatan yang menimbulkan akibat yang dilarang, dan yang diancam sanksi pidana ialah orang yang melakukan perbuatan yang menimbulkan akibat yang dilarang tersebut.

Dalam berbagai artian tindak pidana bisa juga disebut dengan delik atau perbuatan yang boleh dihukum atau peristiwa pidana itu adalah suatu perbuatan yang melanggar atau bertentangan dengan undang-undang yang dilakukan dengan kesalahan oleh orang-orang yang dapat dipertanggungjawabkan. ${ }^{3}$

Pertanggungjawaban pidana di atas ditegakkan atas tiga hal, yaitu:

1. Adanya perbuatan yang dilarang.

2. Dikerjakan dengan kemauan sendiri.

1 Rahmat Hakim, Hukum Pidana Islam (Fiqh Jinayah) (Bandung: Pustaka Setia, 2000), 11.

2 Nafi' Mubarok, Suplemen Pengetahuan Hukum Pidana (Surabaya: Fakultas Syariah dan Hukum UIN Sunan Ampel, 2017), 21.

3 Mubarok, 21-22. 
3. Pembuatnya mengetahui terhadap akibat perbuatan tersebut. ${ }^{4}$

Kalau ketiga hal tersebut ada, maka terdapat pula pertanggungjawaban pidana, dan kalau tidak ada maka tidak ada pertanggungjawaban pidana. ${ }^{5}$ Dengan demikian ketiga hal tersebut adalah unsur-unsur dari pertanggungjawaban pidana.

Meskipun sudah mendapatkan reaksi social, namun secara statistik kejahatan terus meningkat. Baik dari sisi kuantitas maupun kualitasnya. Bahkan bentuk-bentuknya juga semakin variatif dan cenderung "kreatif". ${ }^{6}$

Salah satu kejahatan atau tindak pidana adalah apa yang terjadi pada tahun 2004. Detailnya ketika pertandingan Persebaya melawan Persela, dimana massa suporter sepakbola $^{7}$ Surabaya yang dikenal nama bonek telah melakukan pengrusakan fasilitas Stadion 10 Nopember Tambaksari. Seluruh tempat duduk untuk ofisial tim dan pelaksana pertandingan hancur total. Sebagian tempat duduk ofisial tim dibakar perusuh. Papan iklan yang terpasang di sekeliling Stadion Tambaksari berantakan total karena dibongkar paksa perusuh. Ironisnya, bongkaran kayu papan reklame ini dipakai oleh para suporter untuk melempari polisi dan pemain kedua tim. ${ }^{8}$

Keberingasan massa juga tertuju ke mobil operasional ANTV yang menyiarkan langsung pertandingan tersebut. Suzuki APV bernopol B 8743 KR milik antv

${ }^{4}$ Muhammad Rizal Fahmi, "Overmacht dalam Tindak Pidana Penganiayaan yang Menyebabkan Korban Meninggal Dunia Perspektif Fiqh Jinayah," Al-Jinâyah: Jurnal Hukum Pidana Islam 1, no. 2 (t.t.): 404.

5 Mubarok, Suplemen Pengetahuan Hukum Pidana, 29.

6 Nafi' Mubarok, "Pidana Qiṣās dalam Prespektif Penologi," Jurnal Al-Qānūn 20, no. 2 (Desember 2017): 224.

7 Terdapat anggapan bahwa suporter sepak bola merupakan pemain keduabelas yang dibilang paling fanatik dan antusias dalam membela klub yang dicintainya. Susah maupun senang, hati mereka melebur menjadi satu saat tim mereka berjuang meraih kemenangan. Lihat: Dewi Suci Kusuma Astuti dan Retno Wulandari Hariyadi, "Kajian Kriminologis Aksi Kekerasan Suporter Sepakbola," Recidive 2, no. 2 (Mei-Agustus 2013): 155.

8 "Bonek Mengamuk, Stadion Rusak Berat Puluhan Penonton Luka, Tujuh Tersangka Ditangkap," Suara Merdeka, Senin, Agustus 2004. 
langsung dibakar hebat, begitu massa melemparkan rokok dan korek api yang menyala ke dalam tangki bensinnya. Kaca depan Toyota Dyna milik antv juga pecah.

Kerugian lebih berat dialami Telkom Surabaya Timur yang digandeng antv sebagai mitra kerja siaran langsung pertandingan. Tercatat dua mobil pemancar milik Divisi Long Distance Representative Office Telkom hancur lebur dirusak massa, Kerusakan Daihatsu Hi-line bernopol L 1225 JB milik Telkomter sebut mirip mobil operasional ANTV yang letaknya memang berdekatan Disulut tangki bensinnya, Namun, yang paling diprihatinkan Telkom Surabaya Timur adalah kerusakan yang menimpa Nissan Diesel L 7612 Y, mobil operasional yang lain. Maklum, selain rusak berat, banyak peralatan teknis yang dicuri. Salah satunya adalah spectrum analyzer, yang nilainya berkisar antara Rp 300 juta.

Dalam Hukum Indonesia yang mengacu pada Kitab Undang-undang Hukum Pidana (KUHP) dijelaskan bahwa kerusuhan terhadap kepentingan umum bisa dituntut dengan hukuman minimal 7 tahun penjara.

Di sisi lain, Islam juga melarang kerusuhan baik itu berupa pembakaran, penganiayaan, pelukaan dan pembunuhan sebagaimana dalam QS. Al Baqarah ayat 11, yang artinya: "Dan bila dikatakan kepada mereka: Janganlah kamu membuat kerusakan di muka bumi, mereka menjawab: "Sesungguhnya kami orang-orang yang mengadakan perbaikan".

Tetapi dalam Islam kerusuhan dan pengrusakan yang dilakukan oleh massa supporter sepakbola tersebut hukumannya masih shubhat karena terdapat berbagai unsur tindak pidana. Hukuman pokok pada hal-hal (kekurangan bukti dan shubhat) tersebut tidak boleh dijatuhkan, karena dengan adanya perbedaan pendapat Ulama', keraguan, serta shubhat, status hukuman qișās $s^{9}$ atau diyah berpindah menjadi hukuman ta'zir.

9 Qiṣāṣ hanya pada kejahatan yang berhubungan dengan jiwa (pembunuhan) dan badan (penganiayaan). Untuk penganiayaan maka harus dibalas seperti penganiayaan yang dilakukan. Semisal seseorang yang memotong 
Jadi hukuman ta'zir berfungsi sebagai hukuman pengganti dari hukuman pokok yang tidak dapat dijatuhkan. ${ }^{10}$ Prinsip penjatuhan ta'zir yang menjadi wewenang penuh adalah Ulul-Amri, artinya baik bentuk maupun jenis hukumannya merupakan hak penguasa. ${ }^{11}$

\section{Kerusuhan Massa dalam KUHP}

Definisi kerusuhan menurut bahasa adalah sesuatu yang membuat rusuh atau kacau, baik itu, perampokan, pembakaran. ${ }^{12}$ Sedangkan menurut Andi Hamzah bahwa delik kerusuhan tidak persis sama dengan delik kekerasan. Banyak delik kerusuhan terjadi pada kejadian kekerasan, akan tetapi ada juga delik kekerasan yang tidak terjadi kerusuhan, misalnya perkosaan dan pemerasan. ${ }^{13}$

Adapun dalam KUHP banyak sekali delik-delik yang berhubungan dengan kerusuhan. Baik itu kerusuhan yang mempunyai unsure penganiayaan, pembakaran dan pengerusakan. ${ }^{14}$ Antara lain Pasal 170 tentang kejahatan terhadap kepentingan umum yang berbunyi: "bersama-sama melakukan kekerasan secara terang-terangan terhadap orang atau barang dipidana dengan pidana penjara selamalamanya lima tahun enam bulan". Dan masih banyak delikdelik yang berhubungan dengan kerusuhan dalam KUHP.

tangan harus dibalas dengan potong tangan pula. Lihat: Mubarok, "Pidana Qiṣās dalam Prespektif Penologi," 228-29.

10 Pemberlakuan ta'zỉr dilandasi filosofi bahwa mencegah lebih baik daripada mengobati, di samping juga sistem pidana yang ketat dan efektif demi untuk mencapai perdamaian dan stabilitas masyarakat. Lihat: Nafi' Mubarok, "Tujuan Pemidanaan dalam Hukum Pidana Nasional dan Fiqh Jinayah," Jurnal AlQanun 21, no. 2 (Desember 2015): 312.

${ }^{11}$ Hakim, Hukum Pidana Islam (Fiqh Jinayah), 143-44.

12 Sudarsono, Kamus Lengkap Bahasa Indonesia (Surabaya: Amelia, 2003), 379.

13 Andi Hamzah, Delik-delik Kekerasan dan Delik-delik yang Berkaitan dengan Kerusuhan (Jakarta: Sumber Ilmu Jaya, 1998), 11.

14 Dewi Suci dan Retno Wulandari mengungkapkan, bahwa beberapa tindak pidana terkait dengan kerusuhan suporter sepak bola ada tiga. Pertama, tindak pidana tentang penghancuran atau perusakan barang, sebagaimana dalam Bab XXVII KUHP. Kedua, tindak pidana penganiayaan, sebagaimana dalam Bab XX KUHP. Ketiga, tindak pidana penghinaan,sebagaimana dalam Pasal 310 ayat (1) KUHP. Lihat: Astuti dan Hariyadi, "Kajian Kriminologis Aksi Kekerasan Suporter Sepakbola," 157-58. 
Sanksi pidana sebagai ketentuan yang mengatur penganiayaan dapat ditemukan dalam ketentuan pasal 170 KUHP, yang menyebutkan bahwa: "Penganiayaan yang diancam dengan dengan pidana penjara selama-lamanya tujuh tahun, kalau ia dengan sengaja merusak barang atau jikalau kekersan yang dilakukannya menyebabkan orang mendapat luka." Jika perbuatan mengakibatkan luka berat yang bersalah dikenakan pidana penjara paling lama lima tahun sembilan tahun. Jika mengakibatkan mati, dikenakan pidana penjara dua belas tahun. Penganiayaan disamakan "sengaja merusak kesehatan". Percobaan untuk melakukan kejahatan ini tidak dipidana.

Seseorang dapat dikenakan sanksi pidana penganiayaan haruslah memenuhi unsur-unsur yang terkandung dalam Pasal 170 KUHP, yaitu:

1. Adanya perbuatan penganiayaan.

2. Menimbulkan luka, sebagaimana dalam ayat (1).

3. Menimbulkan luka berat, sebagaimana dalam ayat (2)

4. Menimbulkan matinya seseorang, sebagaimana dalam ayat (3).

Kerusuhan dalam KUHP yang berbentuk penganiayaan, sebagaimana dalam Pasal 170 KUHP di atas bisa dijelaskan sebagai berikut:

1. Bahwa bersama-sama melakukan kekerasan secara terang terangan terhadap orang atau barang dipidana dengan pidana penjara selama-lamanya lima tahun enam bulan.

2. Yang bersalah dipidana:

a. Dengan pidana penjara selama-lamanya tujuh tahun, kalau ia dengan sengaja merusak barang atau jikalau kekersan yang dilakukannya menyebabkan orang mendapat luka.

b. Dengan pidana penjara selama-lamanya sembilan tahun jikalau kekersan yang dilakukannya menyebabkan orang mendapat luka berat. 
c. Dengan pidana penjara selama-lamanya dua belas tahun jikalau kekersan yang dilakukannya menyebabkan matinya orang. ${ }^{15}$

Sedangkan sangsi hukum bagi kerusuhan menurut KUHP bahwa unsur perbuatan berkaitan dengan pertanggungjawaban seseorang yang melakukan suatu perbuatan atau tindakan yang dilakukan. Oleh karena itu, unsur perbuatan berkaitan erat dengan kesengajaan atau kelalaian seseorang melakukan suatu perbuatan yang dalam hal ini penganiayaan.

Perbuatan pidana penganiayaan yang dilakukan seseorang dapat merupakan suatu kesengajaan atau kelalaiannya. Kesengajaan dilakukan mengingat pelaku sadar bahwa perbuatan penganiayaan dapat mengakibatkan penganiayaan direncanakan secara terang. ${ }^{16}$

Ketentuan pidana percobaan dapat ditemukan dalam ketentuan pasal 351 ayat (5) dan pasal 342 ayat (2). Ketentuan pasal ini juga diterapkan dalam memeriksa supporter sepak bola yang telah melakukan percobaan penganiayaan sebagaimana yang dijelaskan kanit bimas polsekta Bubutan Surabaya.

Seseorang yang hendak melakukan percobaan penganiayaan, setelah ditangkap lalu diamankan ke kantor polsekta atau pos keamanan setempat, kemudian diberikan pengarahan, lalu dilepas dengan catatan supporter tidak melakukan perbuatan brutal lagi.

Tindak kejahatan penganiayaan ringan telah diatur dalam ketentuan pasal 342 ayat (1) KUHP, yang menyebutkan: "Kecuali yang tersebut dalam pasal 352 dan 356, maka penganiayaan yang tidak menimbulkan penyakit atau halangan untuk menjalankan pekerjaan jabatan atau pencarian,diancam pidana penjara paling lama 3 bulan atau paling banyak tiga ratus rupiah".

15 R. Soegandhi, Kitab Undang-undang Hukum Pidana dan Penjelasannya (Surabaya: Usaha Nasional, 1981), 191.

16 Alfan Maulidin Ichwanto, "Tindak Pidana Penganiayaan dalam Hukum Pidana Islam," Jurnal Al-Qānūn 20, no. 1 (Juni 2017): 194. 
Dalam mengkatagorikan seorang seseorang telah melakukan perbuatan pidana penganiayaan ringan, dalam prakteknya ukuran yang digunakan adalah "apakah si korban dirawat di rumah sakit atau tidak". Pasal 31 ayat (2) KUHP juga pasal 354 ayat (1) KUHP, dapat ditemukan ketentuan penganiayaan berat dan/atau sampai meninggal dunia untuk dapat dinyatakan sebagai "luka berat".

Dengan demikian seseorang yang melakukan perbuatan penganiayaan, sehingga korban dalam kondisi seperti yang dimasud pasal $90 \mathrm{KUHP}$, maka dinyatakan telah melakukan penganiayaan berat.

Penganiayaan yang direncanakan dengan tenang diatur dalam ketentuan pasal 353 KUHP, dimana si pelaku terlebih dahulu ada unsur niat yang disengaja. Dari niat untuk melakukan perbuatan penganiayaan tersebut agar maksud tercapai terlebih dahulu direncanakan. Dalam prakteknya, seseorang ada juga yang mempunyai niat untuk melakukan perbuatan penganiayaan. Terlebih dahulu seseorang telah menyiapkan rencana segala sesuatunya. Biasanya hal tersebut timbul karena seseorang mempunyai rasa dendam terhadap korbannya, sehingga ia mempunyai niatan untuk melakukan pembalasan. Sanksi pidana yang direncanakan ini sangatlah berat, berupa hukuman penjara paling lama tujuh tahun sampai dengan sembilan tahun. ${ }^{17}$

Dengan demikian uraian tentang kerusuhan dalam perspektif KUHP, dan perhatikan bahwa pertangung jawaban harus memenuhi unsure dalam ketentuan pasal 351 KUHP harus terpenuhi. Apabila unsure tersebut terpenuhi, maka si pelaku dapat disidangkan di pengadilan dan dijatuhkan sanksi pidana sesuai perbuatan yang telah dilakukannya. ${ }^{18}$

\section{Kerusuhan Massa dalam Perspektif Hukum Islam}

17 Fahmi, "Overmacht dalam Tindak Pidana Penganiayaan yang Menyebabkan Korban Meninggal Dunia Perspektif Fiqh Jinayah," 401.

18 Abdurrohman, "Pertimbangan Hakim Pengadilan Negeri Mojokerto tentang Anak yang Melakukan Penganiayaan Menurut Hukum Islam," Al-Jinâyah: Jurnal Hukum Pidana Islam 2, no. 1 (Juni 2016): 81. 
Seperti dijelaskan diatas bahwa kerusuhan itu identik dengan kekerasan dalam istilah arab digunakan istilah jinayah atau jarimah untuk menyebut pidana, jināyah diambil dari kata jana-yajny, yang artinya memetik. Perkataan "jana-' 'ala qaumihi jinayatan" mempunyai arti "ia telah melakukan tindakan kriminal terhadap kaumnya."19

Secara istilah, Abdul Qodir Audah mendefinisikannya sebagai berikut: "Jinayah adalah suatu istilah untuk perbuatan yang dilarang oleh Syara', baik perbuatan tersebut mengenai jiwa, harta atau lainya." 20

Dalam arti luas, jinayah merupakan perbuatan yang dilarang oleh syara' dan dapat mengakibatkan hukuman hadd, atau ta'zír. Sedangkan dalam arti sempit, jinayah merupakan perbuatan-perbuatan yang dilarang oleh syara' dan dapat menimbulkan hukuman hadd, bukan ta'zir. ${ }^{21}$

Menurut ahli fiqh, kategori kerusuhan dalam hukum Islam adalah tindak pidana menyakiti badan dan tidak sampai menghilangkan nyawa orang. Baik itu menyakiti, melukai, memukul, menarik, memeras, memotong rambut, mencabut rambut, pembakaran dan lain sebagainya. ${ }^{22}$

Para ahli hukum Mesir menafsirkan bahwa yang dimaksud dengan penganiayaan adalah melukai dan memukul saja. ${ }^{23}$ Tetapi tidak sampai menghilangkan nyawa orang tersebut, hal ini termasuk tindak pidana penganiayaan. Dan apabila perbuatan tersebut berakibat menghilangkan nyawa orang lain hal ini termasuk pembunuhan. ${ }^{24}$

Adapun unsur-unsur pidana penganiayaan ada tiga, yaitu:

${ }^{19}$ Sayyid Sābiq, Fikih Sunnah, trans. oleh Husein Nabhan, Juz 10 (Bandung: Al-Ma'arif, 1987), 11.

20 Abdul Qodir 'Audah, Al-Tashri’ al-Jinaìy al-Islämy, Juz 2 (Beirut: Dār alMa'rifah, 1992), 67.

${ }^{21}$ Ahmad Djazuli, Fiqih Jinayah (Jakarta: Raja Grafindo Persada, 1996), 2. 191.

22 Ichwanto, "Tindak Pidana Penganiayaan dalam Hukum Pidana Islam,"

23 'Audah, Al-Tashrỉ al-Jinäiy al-Islämy, 204.

24 Abdurrohman, "Pertimbangan Hakim Pengadilan Negeri Mojokerto tentang Anak yang Melakukan Penganiayaan Menurut Hukum Islam," 81. 
1. Perbuatan menimbulkan rasa sakit atau luka pada badan orang lain.

2. Tidak dengan maksud patut atau dengan kata lain melewati batas yang diizinkan.

3. Perbuatan diiringi dengan niat ingin menyakiti orang lain. ${ }^{25}$

Menurut ahli fiqh, kategori kerusuhan dalam hukum Islam adalah termasuk dalam tindak pidana "menyakiti badan dan tidak sampai menghilangkan nyawa orang". Adapun hukuman terhadap pelaku jarimah pelukaan adalah qișaș, ${ }^{26}$ atau diyah bila syarat-syarat qișas tidak terpenuhi. ${ }^{27}$ Dalam hadis| Nabi yang diriwayatkan oleh Ibnu Syuraikh alKhuza'i ditegaskan: "Siapa yang terbunuh familinya sesudah saya berkata ini, maka ahli warisnya mempunyai salah satu dari dua pilihan, yaitu menerima diyah atau balas membunuh."

Di samping itu, juga bisa dikenakan ta'zir, yaitu hukuman yang ditetapka atas perbuatan manusia atau jinayah yang tidak dikenakan hukuman hadd dan tidak ada kaffärah". ${ }^{28}$ Dengan demikian bahwa ta'zir adalah suatu hukuman atas jarimah yang kadar hukumnya belum ditetapkan oleh syara' (Al-Qur'an dan Hadist), yang mempunyai tujuan memberikan tindakan edukatif kepada pelaku sehingga menyadari atas perbuatan yang telah dilakukan dan tidak mengulanginya lagi perbuatan tersebut. ${ }^{29}$ Hukuman ta'zir boleh dan harus ditetapkan sesuai dengan tuntutan kemaslahatan. ${ }^{30}$ 192.

25 Ichwanto, "Tindak Pidana Penganiayaan dalam Hukum Pidana Islam,"

26 Mubarok, "Pidana Qiṣās dalam Prespektif Penologi," 229.

27 Fahmi, "Overmacht dalam Tindak Pidana Penganiayaan yang Menyebabkan Korban Meninggal Dunia Perspektif Fiqh Jinayah," 404.

${ }^{28}$ Ahmad Wardi Muslich, Pengantar dan Asas Hukum Pidana Islam (Jakarta: Sinar Grafika, 2004), 249.

29 Pemberlakuan ta'zir dilandasi filosofi bahwa mencegah lebih baik daripada mengobati, di samping juga sistem pidana yang ketat dan efektif demi untuk mencapai perdamaian dan stabilitas masyarakat. Lihat: Mubarok, "Tujuan Pemidanaan dalam Hukum Pidana Nasional dan Fiqh Jinayah," 312.

${ }^{30}$ Djazuli, Fiqih Jinayah, 166. 
Pada dasarnya, sanksi ta'zír memberikan pengajaran sebagai hukuman preventif dan represif serta kuratif dan eduatif. ${ }^{31}$ Dengan sanksi ta'zir ini maka dimaksudkan tidak boleh membawa ke arah kehancuran. ${ }^{32}$ Fungsi preventif 33 adalah sanksi ta'zir yang diberikan kepada pelaku tindak pidana harus memberikan dampak positif bagi orang lain atau orang yang tidak dikenai hukuman ta'zirr, sehingga orang lain tidak melakukan perbuatan yang sama dengan perbuatan terhukum.

Sedangkan fungsi represif ${ }^{44}$ adalah sanksi $t a^{\prime} z i r$ harus memberikan dampak positif bagi pelaku, sehingga ia sadar dan tidak lagi melakukan perbuatan yang menyebabkan dirinya dijatuhi hukuman ta'zir. Adapun fungsi edukatif 35 adalah sanksi ta'zir harus mampu mengubah pola pikir terhukum untuk menjauhi perbuatan maksiat, bukan disebabkan takut karena hukuman. Tetapi semata-mata karena ia tidak senang terhadap kejahatan. Oleh karena itu, pendidikan agama menjadi bagian terpenting untuk memperkuat iman dan ketakwaan seseorang. Dan, fungsi

31 Menurut Muh. Tahmid Nur, bahwa tujuan pemidanaan dalam Hukum Pidana Islam adalah sebagai retribution (pembalasan) semata, deterrence (pencegahan) dan reformation (perbaikan), serta mengandung tujuan pendidikan (al-tahzib) bagi masyarakat, yang merupakan satu kesatuan yang utuh dalam penerapannya demi mewujudkan kemaslahatan manusia. Lihat: Mubarok, "Tujuan Pemidanaan dalam Hukum Pidana Nasional dan Fiqh Jinayah," 313.

32 Muslich, Pengantar dan Asas Hukum Pidana Islam, 272.

33 Pencegahan adalah menahan orang yang berbuat jarimah agar ia tidak mengulangi perbuatan jarimahnya atau ia tidak akan terus-menerus melakukan jarimah tersebut. Pencegahan juga mengandung arti mencegah orang lain selain pelaku agar ia tidak ikut melakukan jarimah. Lihat: Fransiska Nurin Nikmah, "Tinjauan Fiqh Jinayah terhadap Tindak Pidana Penganiayaanyang Dilakukan Anak di Bawah Umur," Jurnal Al-Qānūn 18, no. 1 (Juni 2015): 44.

34 Jimly Asshiddiqie menyatakan, "Penjatuhan pidana ḥudūd dimaksudkan untuk mencegah terjadinya kejahatan lebih lanjut dalam masyarakat dengan cara melindungi kebaikan dan memberikan ganjaran kepada pelaku kejahatan dengan perspektif untuk membela orang yang tertindas danyang menjadi korban. Lihat: Mubarok, "Tujuan Pemidanaan dalam Hukum Pidana Nasional dan Fiqh Jinayah," 316.

35 Tujuan penjatuhan hukuman dalam Fiqh Jinaya adalah mendidik pelaku jarimah agar ia menjadi orang yang baik dan menyadari kesalahannya. Lihat: Nikmah, "Tinjauan Fiqh Jinayah terhadap Tindak Pidana Penganiayaanyang Dilakukan Anak di Bawah Umur," 44. 
kuratif (islah) adalah sanksi ta'zir harus mampu merubah sikap pelaku tindak pidana dalam menjalankan hukum di kemudian hari.

\section{Analisis Yuridis Tentang Kerusuhan Massa Menurut KUHP dan Hukum Islam}

Kerusuhan dalam hukum positif terdapat batasan batasan yang telah menjadi pedoman Negara dalam menentukan hukuman bagi pelaku tindak pidana, yaitu KUHP. Baik kasus kerusuhan itu berhubungan dengan pembakaran, pelukaan, atau penganiaayaan.

Pada dasarnya aksi kerusuhan yang dilakukan oleh supporter disebabkan oleh beberap faktor. Antara lain faktor "rasa fanatik" kedaerahan yang berlebihan, faktor sumber daya manusia yang berada di lingkungan sepakbola, faktor sosial budaya yang terjadi dimasyarakat dan fasilitas olahraga yang masih minim merupakan faktor kriminogen untuk terjadinya kejahatan kekerasan yang dilakukan oleh suporter sepakbola. ${ }^{36}$

Dalam aksi brutalnya di luar stadion suporter juga melakukan tidak pidana, sebagaimana diatur dalam KUHP sehingga pelaku dapat dipidana. Perbuatan pidana pencurian yang diatur dalam pasal 362 KUHP, juga sering terjadi dan dilakukan oleh supporter. Kesempatan adanya pertandingan sepak bola, suporter menggunakan kesempatan untuk melakukan pencurian, semisal pencurian sepeda motor yang tidak di parkir pada tempatnya. Juga, mencopet dan sebagainya.

Tentunya suporter tersebut akan dikenai sanksi pidana jika telah memenuhi unsur-unsur dalam ketentuan Pasal 362 KUHP, sebagai berikut :

a. barang siapa,

b. mengambil sebagian atau seluruhnya kepunyaan orang lain dan

c. dengan maksud untuk memiliki secara melawan hukum

36 Astuti dan Hariyadi, "Kajian Kriminologis Aksi Kekerasan Suporter Sepakbola," 161. 
Pemerasan, sebagaimana diatur dalam Pasal 368 KUHP, juga banyak dilakukan oleh suporter sepak bola. Apabila suporter menginginkan sesuatu barang atau uang, maka mereka sering secara paksa meminta kepada orang atau pedagang yang ditemui. Unsur-unsur yang harus dipenuhi sebagaimana dalam pasal 368 KUHP, sehingga seorang suporter dapat dikenai sanksi pidana adalah sebagai berikut:

a. barang siapa,

b. dengan maksud menguntungkan diri sendiri, atau orang lain secara melawan hukum,

c. memaksa seseorang dengan kekerasan, atau ancaman kekerasan untuk memberikan sesuatu barang dan

d. sesuatu barang itu milik orang atau orang lain.

Tidak jarang pula suporter melakukan pengerusakan suatu benda milik orang maupun fasilitas umum. Tentunya ini jelas bahwa dia telah melanggar ketentuan pasal 406 ayat (1) KUHP. Suporter di sepanjang jalan yang dilaluinya telah melakukan pengerusakan terhadap mobil-mobil, rumah atau took-toko dengan jalan melempari dengan batu maupun memukul dengan tongkat kayu yang dibawa. Tak ketinggalan pula fasilitas umum yang juga dirusak oleh suporter sepak bola, seperti telepon umum dan pot-pot tanaman di sepanjang jalan. Dalam hal ini, maka dia telah memenuhi unsur-unsur sebagaimana terdapat dalam ketentuan pasal 406 ayat (1) sebagai berikut:

a. barang siapa,

b. dengan sengaja dan melawan hukum menghancurkan, merusak, membikin tak dapat dipakai atau menghilangkan barang sesuatu dan

c. barang tersebut, sebagian atau seluruhnya kepunyaan orang lain. ${ }^{37}$

Kerusuhan yang dilakukan suporter sepak bola di dalam stadion lapangan sepak bola, pada dasarnya sama sebagaimana yang diuraikan di atas. Tetapi kerusuhan yang terjadi di dalam stadion yang besar kemungkinannya adalah

${ }^{37}$ Soegandhi, Kitab Undang-undang Hukum Pidana dan Penjelasannya, 195. 
melakukan penganiayaan, sebagaiaman diatur dalam ketentuan Pasal 351 KUHP. Bentuknya berupa penganiayaan yang dilakukan antara suporter 2 (dua) kesebelasan yang bertanding, berkelahi yang menyebabkan luka-luka ringan, luka-luka berat ataupun dapat meninggal dunia. Pengerusakan sarana dan prasarana stadion, semisal bangku, pagar pembatas, pintu gerbang dan sebagainya, di dalam stadion juga sering dilakukan oleh suporter.

Dan uraian penjelasan kerusuhan yang dilakukan suporter sepak bola tersebut di atas, maka dapat diketahui pula akibat-akibat yang ditimbulkan dari peristiwa kerusuhan tersebut. Secara umum akibat yang ditimbulkan adalah kerigian material bagi Negara dalam pelaksanaan pembangunan nasional dimana pada salah satu sector terhambat. Kerusuhan yang terjadi menghambat arus pelaksanaan pembangunan, misalnya: kerusakan stadion sepak bola, fasilitas umum, kemacetan arus lalu lintas jalan raya dan lain sebagainya

Jelaslah hal itu menimbulkan kerugian material yang sangat besar bagi Negara, sehingga memerlukan dana yang besar untuk pemulihannya. Selain itu waktu pelaksanaan suatu sector pembangunan juga mengalami gangguan dan hambatan yang seharusnya dapat terselesaikan pada waktunya. Kerusuhan suporter sepak bola merupakan suatu keadaan yang mengakibatkan keprihatinan nasional, sehingga kerugian immaterial juga dirasakan oleh bangsa Indonesia.

Suporter yang telah ditangkap oleh penyidik langsung dilakukan penyidikan, guna dibuat berita acara pemeriksaan atas perbuatan pidana yang dilakukan. Atas pemeriksaan tersebut, penyidik dapat melakukan penahanan sesuai dengan pasal 20 ayat (1) KUHP, sebagai berikut: "Untuk kepentingan penyidik atau penyidik pembantu atas perintaqh penyidik sebagaimana dimaksud dalam pasal 11 berwenang melakukan penahanan".

Jenis penahanan suporter yang melakukan kerusuhan dapat berupa :

a. penahanan rumah tahanan Negara 


\section{b. penahanan rumah \\ c. penahanan kota}

Penahanan kota dilaksanakan di kota tempat tinggal atau tempat kediaman tersangka atau terdakwa, dengan kewajiban bagi tersangka atau terdakwa melapor dan pada waktu tertentu. Yaitu batas waktu berkas perkara diserahkan pada kejaksaan untuk dapat diajukan sidang di pengadilan.

Perihal penangkapan dan penahanan telah diatur dalam Kitab Undang-undang Hukum Acara Pidana (KUHAP) dalam Bab V dan Bagian Kedua, pasal 16-30. Penangkapan dan penahanan merupakan upaya awal dalam proses si pelaku akan dikenakan sanksi pidana oleh pengadilan.

Dalam ketentuan pasal 1851 ayat ( 1 ) KUH Perdata, menyebutkan: "Perdamaian adalah suatu persetujuan dengan mana kedua belah pihak, dengan menyerahkan, menjanjikan atau menahan suatu barang, mengakhiri suatu perkara yang sedang bergantung ataupun mencegah timbulnya suatu perkara". Penyelesaian ganti rugi tersebut berdasarkan atas kesepakatan kedua belah pihak, akhirnya dibuat kata perdamaian yang isinya kesepakatan kedua belah pihak. Dalam pelaksanaan proses perdamaian tersebut, sesuai dengan kesepakatan maka suporter diwajibkan membayar ganti rugi kepada si korban.

Berdasarkan atas ketentuan pasal 1851 KUHperdata, menyebutkan: "Persetujuan itu tidak sah, melainkan dibuat secara tertulis". Pembayaran ganti rugi oleh suporter yang melakukan pengerusakan dalam proses pemeriksaan, harus dibuat akta yang tertulis. Pernyataan tersebut merupakan kesepakatan, yang mempunyai kekuatan berlaku bagi pihak yang dirugikan, sehingga bermaksud menyelesaikan perkara perdatanya.

Walaupun perkara yang diperiksanya merupakan perkara pidana, maka penyelesaian keperdataan dapat dilakukan. Hal tersebut diatur dalam ketentuan pasal 1853 KUH Perdata, menyebutkan: "Tentang kepentingankepentingan keperdataan yang terbit dalam suatu kejahatan atau pelanggaran dapat diadakan perdamaian". 
Dengan demikian cukuplah jelas bahwa dalam perkara pidana dapat diselesaikan terlebih dahulu perkara perdatanya yang terkait dengan masalah ganti rugi. Sedangkan perkara pidana yang dilakukan oleh supporter tetaplah berjalan proses pemeriksaan sampai pada penuntutan dan penjatuhan putusan oleh hakim pengadilan. Hal tersebut dapat diketahui dalam ketentuan pasal 1853 ayat ( 2 ) KUHP perdata, menyebutkan : "Perdamaian ini tidak menghalangi jawatan kejaksaan untuk menuntut perkaranya". Upaya perdamaian gugatan ganti rugi, dalam proses pemeriksaan sangatlah baik dengan mengingat perkara perdata lebih cepat, dan tidak perlu menunggu putusan pidana si pelaku (suporter).

\section{Analisis Yuridis tentang Kerusuhan Massa Menurut KUHP dan Hukum Islam}

Menurut hukum Islam, ahli fiqh mengkategorikan kerusuhan termasuk dalam tindak pidana "sebab menyakiti badan dan tidak sampai menghilangkan nyawa orang". Baik itu menyakiti, melukai, memukul, menarik, memeras, memotong rambut dan mencabutnya dan lain sebagainya.

Para ahli hukum Mesir menafsirkan bahwa yang dimaksud dengan penganiayaan adalah melukai dan memukul saja. Tetapi tidak sampai menghilangkan nyawa orang tersebut, hal ini termasuk tindak pidana penganiayaaan, dan apabila perbuatan tersebut berakibat menghilangkan nyawa orang lain hal ini termasuk penganiayaan.

Adapun pidana penganiayaan mempunyai unsur niat, yaitu dengan adanya ketentuan yang melarang perbuatan tertentu yang menunjukkan sebagai suatu tindak pidana penganiayaan. Unsur tersebut sesuai dengan prinsip yang menyatakan bahwa suatu tindak pidana penganiayaan belum bisa dikatakan tindak pidana sebelum dinyatakan dalam ketentuan syara', yaitu melakukan perbuatan yang melanggar hukum dan mendapatkan hukuman dari perbuatan tersebut. Selanjutnya pelaku pidana 
penganiayaan yang bisa dikenai hukuman hanyalah atas orang-orang yang baligh.

Adapun jenis kerusuhan yang menghilangkan kehidupan adalah pembunuhan. Menurut Abdul Qadir 'Audah, pembunuhan adalah perbuatan seorang yang menghilangkan kehidupan atau hilangnya roh adami akibat perbuatan manusia yang lain. ${ }^{38}$ Para ulama mendefinisikan pembunuhan dengan suatu perbuatan manusia yang menyebabkan hilangnya nyawa. Ketika terjadi kejahatan ini, maka pelaku dijatuhi hukuman qiṣāṣ, berupa hukuman mati. ${ }^{39}$

Kerusuhan supporter persebaya yang berhubungan dengan kekerasan merupakan jenis qișāṣ. Tetapi dalam hal ini hukuman ini tidak boleh dijatuhkan, karena perbuatan tersebut tidak memenuhi kriteria sebagai jarimah qișās, akibat adanya kesamaran atau shubhat dalam segala aspek, baik pelaku, korban, atau tempat. Penggantinya juga bukan diyah, sebab dalam kasus ini terdapat shubhat atau kesamaran dan bukan pemaafan. Sehingga dalam kasus yang masih samar, jarimah qiṣāṣ tidak dianggap lagi.

Hukuman pokok pada qiṣāṣ tidak dapat dijatuhkan. Begitu pula dengan hukuman penggantinya, yaitu diyah juga tidak dapat dijatuhkan, karena perkaranya masih samar. Maka hukumannya pun menjadi hukuman ta'zir. Jadi hukuman ta'zir berfungsi sebagai hukuman pengganti dari hukuman pokok yang tidak dapat dijatuhkan.

\section{Penutup}

Dari berbagai pemaparan di atas bisa disimpulkan hal-hal sebagai berikut:

1. Kerusuhan massa oleh supporter Persebaya disebabkan oleh fanatisme yang berlebihan, sehingga amuk massa supporter merupakan pelampiasan kekecewaan mereka yang mereka lakukan terhadap lawan maupun fasilitas yang ada.

38 'Audah, Al-Tashri’ al-Jinaìy al-Islämy, 206.

39 Mubarok, "Pidana Qiṣās dalam Prespektif Penologi," 229. 
2. Menurut hukum pidana Islam kerusuhan massa oleh suporter Persebaya sudah termasuk dalam kategori tindak pidana pelukaan, penganiayaan dan pengerusakan. Baik itu tidak sengaja atau karena sengaja. Hal ini dikarenakan di sini kerusuhan Supporter Persebaya melakukan tindakan yang bisa merugikan orang lain, yang tentunya harus diproses secara hukum, baik itu hukum Islam ataupun hukum menurut KUHP.

Selanjutnya diajukan saran sebagai berikut:

1. Bagi Supporter penggemar Sepakbola seyogyanya bersikap sportif dalam menyikapi hasil pertandingan, dengan cara mengedepankan nilai etika pertandingan, khususnya Tim Koordinator Kesebelasan agar lebih antisipasif terhadap segala hal yang kemungkinan terjadi di lapangan sehingga lebih preventif.

2. Bagi para pembaca supaya bersikap kritis dan analis terhadap karya ilmiyah terlebih bidang olahraga Sepakbola, demi konstribusi pemikiran yang lebih memajukan dunia olahraga.

\section{Daftar Pustaka}

Abdurrohman. "Pertimbangan Hakim Pengadilan Negeri Mojokerto tentang Anak yang Melakukan Penganiayaan Menurut Hukum Islam." Al-Jinâyah: Jurnal Hukum Pidana Islam 2, no. 1 (Juni 2016).

Astuti, Dewi Suci Kusuma, dan Retno Wulandari Hariyadi. "Kajian Kriminologis Aksi Kekerasan Suporter Sepakbola." Recidive 2, no. 2 (Mei-Agustus 2013).

'Audah, Abdul Qodir. Al-Tashrỉ al-Jinaìy al-Islamy. Juz 2. Beirut: Dār al-Ma'rifah, 1992.

"Bonek Mengamuk, Stadion Rusak Berat Puluhan Penonton Luka, Tujuh Tersangka Ditangkap." Suara Merdeka, Senin, Agustus 2004.

Djazuli, Ahmad. Fiqih Jinayah. Jakarta: Raja Grafindo Persada, 1996.

Fahmi, Muhammad Rizal. "Overmacht dalam Tindak Pidana Penganiayaan yang Menyebabkan Korban Meninggal Dunia Perspektif Fiqh Jinayah." Al-Jinâyah: Jurnal Hukum Pidana Islam 1, no. 2 (t.t.): Desember 2015. 
Hakim, Rahmat. Hukum Pidana Islam (Fiqh Jinayah). Bandung: Pustaka Setia, 2000.

Hamzah, Andi. Delik-delik Kekerasan dan Delik-delik yang Berkaitan dengan Kerusuhan. Jakarta: Sumber Ilmu Jaya, 1998.

Ichwanto, Alfan Maulidin. "Tindak Pidana Penganiayaan dalam Hukum Pidana Islam." Jurnal Al-Qānūn 20, no. 1 (Juni 2017).

Mubarok, Nafi'. "Pidana Qiṣās dalam Prespektif Penologi." Jurnal Al-Qäūn 20, no. 2 (Desember 2017).

Mubarok, Nafi'. Suplemen Pengetahuan Hukum Pidana. Surabaya: Fakultas Syariah dan Hukum UIN Sunan Ampel, 2017.

Mubarok, Nafi'. "Tujuan Pemidanaan dalam Hukum Pidana Nasional dan Fiqh Jinayah." Jurnal Al-Qanun 21, no. 2 (Desember 2015).

Muslich, Ahmad Wardi. Pengantar dan Asas Hukum Pidana Islam. Jakarta: Sinar Grafika, 2004.

Nikmah, Fransiska Nurin. "Tinjauan Fiqh Jinayah terhadap Tindak Pidana Penganiayaanyang Dilakukan Anak di Bawah Umur." Jurnal Al-Qānün 18, no. 1 (Juni 2015).

Sābiq, Sayyid. Fikih Sunnah. Diterjemahkan oleh Husein Nabhan. Juz 13. Bandung: Al-Ma'arif, 1987.

Soegandhi, R. Kitab Undang-undang Hukum Pidana dan Penjelasannya. Surabaya: Usaha Nasional, 1981.

Sudarsono. Kamus Lengkap Bahasa Indonesia. Surabaya: Amelia, 2003. 